\title{
Characterization of seismogenic crustal faults in the Gulf of Guayaquil, Ecuador
}

\author{
Kervin Chunga ${ }^{1,2}$, Felipe Ochoa-Cornejo ${ }^{3}$, Maurizio Mulas ${ }^{4}$, \\ Theofilos Toulkeridis 5 , Edgar Menéndez ${ }^{2}$
}

\author{
1 Universidad Estatal Península de Santa Elena (UPSE), Facultad de Ciencias de la Ingeniería, Avda. Principal La Libertad, Ecuador. \\ kchunga@upse.edu.ec \\ 2 Universidad Técnica de Manabi (UTM), Facultad de Ciencias Matemáticas, Físicas y Químicas, Departamento de Construcciones \\ Civiles, Av. José María Urbina, Portoviejo 130105, Ecuador. \\ emenendez@utm.edu.ec \\ 3 Universidad de Chile, Departamento de Ingeniería Civil, Avda. Blanco Encalada 2002, Santiago, Chile. \\ fochoa@ing.uchile.cl \\ ${ }^{4}$ Escuela Superior Politécnica del Litoral (ESPOL), Facultad de Ingeniería en Ciencias de la Tierra, Campus Gustavo Galindo \\ Km 30.5 Via Perimetral, P.O. Box 09-01-5863, Guayaquil, Ecuador. \\ mmulas@espol.edu.ec \\ 5 Universidad de las Fuerzas Armadas ESPE, Avda. General Rumiñahui s/n y Ambato, Sangolqui, Ecuador. \\ ttoulkeridis@espe.edu.ec
}

\begin{abstract}
Few moderate-to-strong earthquakes associated with active and capable geological faults have been documented for the southern coastal region of Ecuador. The seismic record of Ecuador initiates with the Guayaquil earthquake in 1787 (Mw 6.5), followed by the 1943 (Mw 6.2), and the most recent one in $1980(\mathrm{Mw}$ 6.1). The available data is insufficient to evaluate the seismic hazards associated with faults capable of generating seismic events of magnitude $\mathrm{Mw} \geq 6.0$ in the region. Also, earthquakes of minor magnitudes can be disregarded as they do not induce significant ground coseismic effects. In this context, this study presents a catalog of geological faults, delineating 40 segments of capable and active faults on the sea floor of the Gulf of Guayaquil and inland segments of Guayas, Santa Elena, and El Oro provinces. This methodological approach estimates a variety of seismicity levels ranging between $\mathrm{Mw} 6.2$ and $\mathrm{Mw}$ 7.2 , with rock peak ground accelerations between $0.24 \mathrm{~g}$ and $0.41 \mathrm{~g}$. These values have been obtained from empirical regression equations applied to the length of capable geological faults. The F-40 seismogenic structure located in the accretionary prism, close to the subduction zone, is capable of generating Mw 8.2 earthquakes and potentially causing coseismic ground damage to the city of Guayaquil located $c a .177 \mathrm{~km}$ to the NE. Furthermore, local tsunami hazards may affect severely areas that are densely populated, with developing industrial areas, on the coast of the Gulf of Guayaquil. This structural geological analysis provides useful new data for seismic hazard assessment.
\end{abstract}

Keywords: Capable fault, Crustal earthquake, Estimated magnitudes, Guayaquil Gulf.

RESUMEN. Caracterización de fallas geológicas capaces de generar terremotos corticales en el Golfo de Guayaquil, costa sur del Ecuador. Terremotos moderados a fuertes, asociados a la tectónica de fallas corticales, han sido poco documentados en la costa sur del Ecuador. La breve historia de registros sísmicos se inicia con el terremoto de Guayaquil, el 11 de junio de 1787 (Mw 6.5), seguido por los terremotos del 30 de enero de 1943 (Mw 6.2), y el 18 de agosto de 1980 (Mw 6.1). Este registro sísmico instrumental proporciona poca información para evaluar el riesgo sísmico por fallas capaces de generar sismos de magnitud mayor o igual a Mw 6.0. Este estudio presenta un catálogo de fallas, delineando 40 segmentos de fallas capaces en el fondo marino del Golfo de Guayaquil y segmentos continentales 
de Guayas, Santa Elena, y El Oro. Este procedimiento metodológico ha permitido estimar niveles de sismicidad con magnitudes que varían entre $\mathrm{Mw}$ 6,2 a Mw 7,2, y aceleraciones en roca, PGA, en el orden de los 0,24 g a los 0,41 g. Estos valores fueron obtenidos con ecuaciones de ajuste aplicadas a fallas geológicas capaces. La estructura sismogénica F-40 localizada en el prisma de acreción (junto a la zona de subducción) es capaz de generar un sismo de magnitud aproximada a Mw 8.2, pudiendo causar daños cosísmicos a la ciudad de Guayaquil, ubicada a aproximadamente a $177 \mathrm{~km}$ de distancia hacia el NE, y también generar tsunamis sobre áreas densamente pobladas, y sectores industriales, asentados en el borde costero del Golfo de Guayaquil. Toda esta información geológica estructural proporciona nuevos datos para considerar en los estudios de peligro sísmico.

Palabras clave: Fallas capaces, Terremotos corticales, Magnitud estimada, Golfo de Guayaquil.

\section{Introduction}

Regression equations applied to kinematic and geometric parameters of both active and capable geological faults have been used in the estimation of the maximum magnitude of earthquakes (Wells and Coppermisth, 1994; Wesnousky, 2008; Leonard, 2010; Stirling et al., 2013), and peak ground acceleration on rocks, PGA(Fukushima and Tanaka, 1990). Empirical relationships between isoseismal area and major axis radius of intensities and values of magnitudes have also been used to determine the seismic epicenter (Marín et al., 2008). Subsequently, this kind of methodology indeed provides estimated values of the levels of seismicity, in particular in areas where the previous seismic history is reduced, or even absent.

The Gulf of Guayaquil in Ecuador is situated on the eastern side of the Pacific Ring of Fire. This is part of an active continental margin where the oceanic Nazca Plate subducts below the South American plate approximately $47 \mathrm{~mm} / \mathrm{yr}$ (Barazangi and Isacks, 1976; De Mets et al., 1990; Trenkamp et al., 2002; Eguez et al., 2003; Veloza et al., 2012). The Nazca Plate includes the aseismic Carnegie Ridge, associated with the Galapagos hot spot magmatism (Shumway, 1954; Lonsdale, 1978; Freymuller et al., 1993; Jaillard et al., 1995; Toulkeridis, 2011). The deformation of continental crust seems to be influenced also by the collision, and mechanical coupling, of the Carnegie Ridge against the South American plate (Gutscher et al., 1999; Dumont et al., 2014). Deformation is partitioned in an NNE-SSW trending strike-slip and reverse faults (Hughes and Pilatasig, 2002). The continental domain is formed of two entities: the Caribbean, and the South-American continental plates. The contact among them corresponds to a deformation zone named Guayaquil-Caracas MegaFault, which extends from the Gulf of Guayaquil in Ecuador until Venezuela (Kellogg and Vega, 1995;
Dumont et al., 2005). As a result of these tectonicbased relationships, two main seismic sources appear in the southern coastal mainland of Ecuador: 1) the tectonic zone of the subduction interface, and 2) the crustal geological faults located within the continental domain.

The main seismogenic structure of the subduction zone is located between $50 \mathrm{~km}$ and $140 \mathrm{~km}$ west of the limits of the Gulf of Guayaquil (Fig. 1). This structure is capable of generating earthquakes of $\mathrm{Mw}$ 8.0 and higher, as documented in the past (Kanamori, 1977; Abe, 1979; Mendoza and Dewey, 1984; White et al., 2003). The Gulf of Guayaquil itself represents a zone with a seismic gap (Contreras, 2013), and therefore, it is feasible to hypothesize that this area probably stores seismic energy, enough to generate an earthquake of magnitude comprise between Mw 6 and Mw 8 (Ioualalen et al., 2014). In this context, this study aims at recognizing and evaluating the seismic potential of crustal faults situated in the offshore of the Gulf of Guayaquil.

The methodology considers the estimation of the lengths of the known active geological faults that can generate earthquakes with magnitudes $\mathrm{Mw} \geq 6.0$, based on works such as those from Well and Coppersmith (1994) and Michetti et al. (2007). Smaller geological faults which may be able to generate earthquakes with a magnitude below Mw 5.5 have not been considered in this study since these earthquakes cause smaller side-effects or coseismic geological effects. As historical earthquakes related with crustal faults are poorly recorded on the mainland at the southern coast of Ecuador (Fig. 1), this methodology will provide a better understanding about the maximum magnitudes of future potential earthquakes, and their associated PGA values. Also, a resulting data set may contribute to determining the seismic hazard level for densely populated and developing industrial areas on the southern coast of Ecuador. 


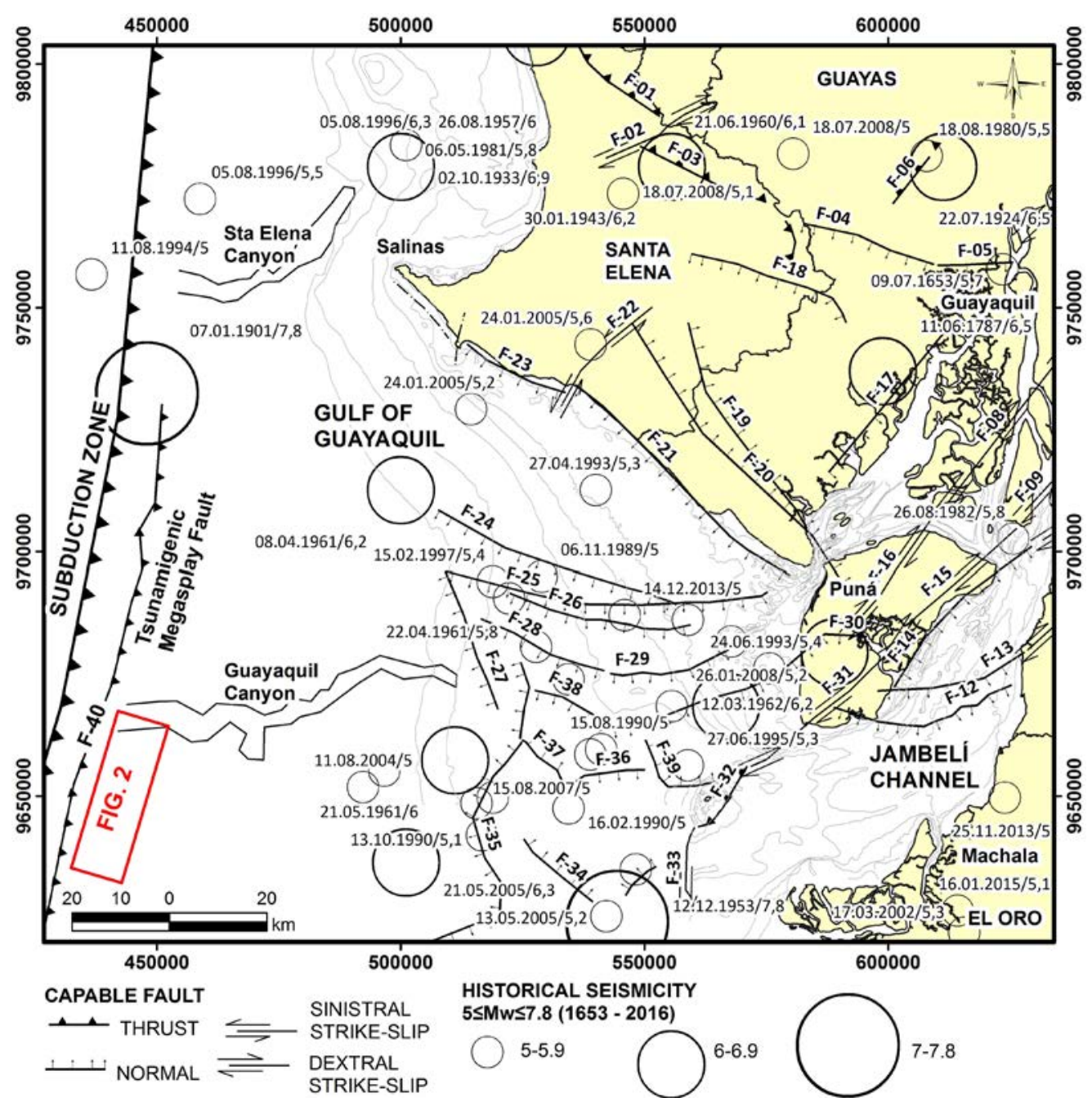

FIG. 1. Seismotectonic map of the Gulf of Guayaquil and continental segment of Santa Elena, Guayas and El Oro Provinces. Historical and instrumental earthquakes obtained from NEIC, CERESIS y RENSIG-EPN catalogs. Crustal faults have been obtained from CEPE (1986), Chunga (2010), Chunga and Quiñónez (2013), Cobos and Montenegro (2010), Eguez et al. (2003), Witt et al. (2006), Witt and Bourgois (2010). Map in UTM, zone $17 \mathrm{~S}$, WGS 84.

\section{Seismic history of Ecuador}

From 1653 until May 2016, the territory of Ecuador recorded 28 earthquakes related with crustal faults and the subduction process, with magnitudes between Mw 5.5 to Mw 7.8 and depths of hypocenters shallower than $20 \mathrm{~km}$ (Table 1). These data document a short record of earthquakes in the Gulf of Guayaquil (Chunga and Quiñonez, 2013). The first earthquake was recorded on July 9, 1653, with a magnitude of Mw 5.7 as converted from macroseismic values
VI (CERESIS, 1985'). On July 11, 1787, the first macroseismic earthquake hit the coastal sector of Ecuador with a possible epicenter in the Guayas province (MHQ, 1879). This event generated building damages and significant coseismic effects on the ground, mainly in the city of Guayaquil, while in nearby towns within a $50 \mathrm{~km}$ radius such damages were not observed (Chunga et al., 2005a). This suggests a shallow hypocenter with the epicenter in or near the city of Guayaquil. Both events (1653 and 1787) are probably associated with crustal 
TABLE 1. MODERATE TO STRONG EARTHQUAKES (GREATER THAN MW 5.5 ), AS DOCUMENTED IN THE CERESIS CATALOG (REGIONAL SEISMOLOGICAL CENTER FOR SOUTH AMERICA) AND RECORDED BY THE NEIC (NATIONAL EARTHQUAKE INFORMATION CENTER).

\begin{tabular}{|c|c|c|c|c|c|}
\hline Date & Lat. & Long. & Mw & Depth & Data Set \\
\hline 09.07 .1653 & -2.19 & -79.89 & 5.7 & ND & CERESIS \\
\hline 11.06 .1787 & -2.38 & -80.11 & 6.5 & 20 & - \\
\hline 07.01.1901 & -2.42 & -81.46 & 7.8 & 25 & CERESIS \\
\hline 22.07 .1924 & -2.00 & -80.00 & 6.5 & ND & CERESIS \\
\hline 02.10 .1933 & -2.00 & -81.00 & 6.9 & 15 & CERESIS \\
\hline 03.10 .1933 & -1.75 & -80.75 & 6.3 & ND & CERESIS \\
\hline 30.01 .1943 & -2.00 & -80.50 & 6.2 & 30 & CERESIS \\
\hline 12.12 .1953 & -3.40 & -80.60 & 7.8 & 30 & CERESIS \\
\hline 12.03 .1957 & -1.59 & -80.15 & 6.2 & 60 & CERESIS \\
\hline 26.08 .1957 & -2.00 & -81.00 & 6 & ND & CERESIS \\
\hline 07.02 .1959 & -3.70 & -81.71 & 7.4 & 33 & CERESIS \\
\hline 12.08 .1959 & -3.00 & -80.50 & 5.7 & 33 & CERESIS \\
\hline 21.06 .1960 & -2.00 & -80.50 & 6.1 & ND & CERESIS \\
\hline 10.09 .1960 & -2.50 & -82.00 & 5.7 & 33 & CERESIS \\
\hline 08.04 .1961 & -2.60 & -81.00 & 6.2 & 25 & CERESIS \\
\hline 22.04 .1961 & -2.80 & -80.80 & 5.8 & 30 & CERESIS \\
\hline 21.05 .1961 & -3.10 & -80.90 & 6 & 27 & CERESIS \\
\hline 02.06 .1961 & -3.00 & -80.40 & 6.2 & 37 & CERESIS \\
\hline 10.12 .1970 & -3.97 & -80.66 & 7.1 & 15 & CERESIS \\
\hline 12.03 .1962 & -2.90 & -80.20 & 6.2 & 25 & CERESIS \\
\hline 18.08 .1980 & -1.98 & -80.03 & 6.1 & 74 & CERESIS \\
\hline 06.05 .1981 & -1.96 & -80.99 & 5.8 & 36 & CERESIS \\
\hline 26.08 .1982 & -2.69 & -79.87 & 5.8 & 70 & NEIC \\
\hline 06.11 .1989 & -2.76 & -80.74 & 5 & ND & EPN \\
\hline 10.02 .1990 & -3.18 & -80.86 & 5.6 & ND & EPN \\
\hline 16.02 .1990 & -3.19 & -80.69 & 5 & ND & EPN \\
\hline 15.08 .1990 & -3.08 & -80.63 & 5 & 19 & EPN \\
\hline 10.02 .1990 & -3.17 & -80.83 & 5.5 & 56 & NEIC \\
\hline 13.10 .1990 & -3.24 & -80.85 & 5.1 & ND & EPN \\
\hline 18.08 .1992 & -2.84 & -80.47 & 5.1 & 0.4 & EPN \\
\hline 27.04 .1993 & -2.60 & -80.64 & 5.3 & 0.3 & EPN \\
\hline
\end{tabular}

\begin{tabular}{|c|r|r|r|c|c|}
\hline Date & Lat. & \multicolumn{1}{|c|}{ Long. } & Mw & Depth & Data Set \\
\hline 24.06 .1993 & -2.93 & -80.32 & 5.4 & 12.3 & EPN \\
\hline 11.08 .1994 & -2.20 & -81.57 & 5 & 11.8 & EPN \\
\hline 26.03 .1995 & -2.05 & -79.75 & 5.3 & 3.3 & EPN \\
\hline 14.06 .1995 & -3.50 & -80.56 & 5.3 & 0.3 & EPN \\
\hline 27.06 .1995 & -3.11 & -80.47 & 5.3 & ND & EPN \\
\hline 13.08 .1995 & -2.89 & -80.75 & 5 & 16 & EPN \\
\hline 05.08 .1996 & -2.06 & -81.37 & 5.5 & 6.6 & EPN \\
\hline 05.08 .1996 & -2.00 & -81.00 & 6.3 & 33 & NEIC \\
\hline 15.02 .1997 & -2.77 & -80.83 & 5.4 & 10 & EPN \\
\hline 16.09 .1998 & -3.50 & -79.68 & 5 & 18.9 & EPN \\
\hline 17.03 .2002 & -3.42 & -79.96 & 5.3 & 17.7 & EPN \\
\hline 11.08 .2004 & -3.15 & -81.07 & 5 & 35.9 & EPN \\
\hline 24.01 .2005 & -2.33 & -80.65 & 5.6 & 28 & NEIC \\
\hline 24.01 .2005 & -2.45 & -80.87 & 5.2 & 20.1 & EPN \\
\hline 09.04 .2005 & -3.55 & -80.30 & 5 & 13.3 & EPN \\
\hline 13.05 .2005 & -3.39 & -80.62 & 5.2 & 13.3 & EPN \\
\hline 21.05 .2005 & -3.29 & -80.99 & 6.3 & 39 & NEIC \\
\hline 21.05 .2005 & -3.51 & -81.33 & 5.5 & 9.3 & EPN \\
\hline 29.05 .2005 & -3.12 & -81.03 & 5.2 & 5.6 & EPN \\
\hline 15.08 .2007 & -3.09 & -80.65 & 5 & 18.3 & EPN \\
\hline 26.01 .2008 & -2.95 & -80.69 & 5.4 & 18 & EPN \\
\hline 18.07 .2008 & -2.05 & -80.59 & 5.1 & 15.7 & EPN \\
\hline 19.07 .2009 & -1.74 & -80.36 & 5.4 & 54 & NEIC \\
\hline 12.05 .2011 & -1.74 & -81.62 & 5 & 10 & NEIC \\
\hline 17.11 .2011 & -1.70 & -81.54 & 6 & 26 & NEIC \\
\hline 13.11 .2012 & -1.73 & -81.57 & 5.1 & 47 & NEIC \\
\hline 25.11 .2013 & -3.16 & -79.88 & 5 & 85 & NEIC \\
\hline 14.12 .2013 & -2.83 & -80.58 & 5 & 55 & NEIC \\
\hline 16.01 .2015 & -3.37 & -79.97 & 5.1 & 79 & NEIC \\
\hline 19.03 .2015 & -3.30 & -80.56 & 5 & 61 & NEIC \\
\hline 28.04 .2015 & -2.08 & -79.62 & 5.4 & 89 & NEIC \\
\hline
\end{tabular}

Moderate earthquakes higher than 5 in the Gulf of Guayaquil and in the peninsula of Santa Elena as well as Guayas provinces are recorded from the local network of the IGEPN. Gray shaded boxes represent the earthquakes near the Gulf of Guayaquil that originated tsunamis with wave heights run-up between 0.2 and $1.8 \mathrm{~m}$. In the event of 1901 the wave heights reached above $2 \mathrm{~m}$ (CERESIS). 
faults, while the following documented registered seismic events are classified as subduction-related earthquakes. On January 7, 1901, an earthquake with a magnitude of $\mathrm{Mw} 7.8$ occurred in front of the Santa Elena Peninsula (CERESIS, 1985). The degree of the macroseismic intensities and the height of a tsunami run-up in the coastal plains of Salinas and La Libertad remained undetermined. The lack of such data did not allow to localize the epicentral area and the corresponding seismogenic features.

Another seismic event with a magnitude of about Mw 6.9, probably linked with the same subduction interface seismic source, occurred on October 2, 1933. Tsunamis waves, as high as $2-2.5 \mathrm{~m}$, flooded without generating turbulent waves in the coastal edge of the Santa Elena peninsula (Silgado, 1957; Espinoza, 1992; Arreaga and Ortiz, 2002). In 1953, between the Ecuadorian-Peruvian border, an earthquake with a magnitude of $\mathrm{Mw} 7.8$ and an epicenter $c a .142 \mathrm{~km}$ to the south of Salinas triggered a tsunamis with a wave height of $20 \mathrm{~cm}$ that impacted the population of La Libertad allowing rapid flooding on the coastal strip of the city of Salinas (Chunga et al., 2005b). Silgado (1957) estimated for this event a macroseismic intensity of VI for the city of Guayaquil.

The earthquake of February 7, 1959 (Mw 7.2) does not provide relevant ground coseismic effects. Four earthquakes with moderate magnitudes (Mw between 6 and 6.2) were reported in the Gulf of Guayaquil from April 1961 to March 1962 (Table 1). The most recent earthquake being an Mw 6.3 occurred on May 21, 2005 and had a focal length $(\mathrm{H})$ of $39 \mathrm{~km}$ (NEIC, 2017). These data suggest that the recurrence of earthquakes with magnitudes greater than $\mathrm{Mw} 6$ is low.

Based on the documented seismic events in the Gulf of Guayaquil, it is necessary to understand what method allows characterizing active or capable faults. This characterization would provide useful insights regarding the seismic potential of this area, based on each of the seismogenic sources, and regarding maximum magnitudes, and Peak Ground Acceleration (PGA).

\section{Ground rock and soil foundation of the Guayaquil area}

In Guayaquil area, the features of rocks and soils change locally: a) the urban and commercial centers are founded on clay soils interbedded with unconsolidated sandy to clayey alluvial Holocene levels; b) the southern and southwestern areas are directly lying on muddy estuarine sediments, where the filling layer has a thickness that varies between $1 \mathrm{~m}$ and $2 \mathrm{~m}$; c) the north of the city is built on Cretaceous hyaloclastite, sandstones, shales, siltstones, and competent greywacke (Cayo and Guayaquil formations); d) the marginal urban areas (Sergio Toral, Monte Sinai, Trinidad de Dios and Horizontes del Fortín) lie mostly on unstable hills slopes; e) the Kennedy and Urdesa sectors are built along two estuarine branches composed of soft unconsolidated sediments. These described lithological features of rocks and soils certainly can amplify or attenuate seismic waves in the ground during an earthquake of magnitude higher than Mw 6.0 (Chunga et al., 2005a; Aguiar et al., 2016).

\section{Morphology of the Gulf of Guayaquil}

The Gulf of Guayaquil is an extensional structure with dextral and sinistral shear faults related with the opening of a fore-arc basin as highlighted by seismic reflection sections (CEPE, 1986²) and by re-evaluations of offshore lithologic logs (Witt et al., 2006; Cobos and Montenegro, 2010). Cobos and Montenegro (2010) define the Gulf of Guayaquil as a "pull-apart" type basin. Regionally, the primary stress regime is associated with the tectonic thrust of the oceanic plate beneath the Gulf of Guayaquil. This tectonic setting favored the uplift of the Paleocene to Holocene lithologic units in coastal margins (Costa et al., 2006). Submarine morphology of the Gulf of Guayaquil is relatively uneven, ranging from the continental shelf to the continental slope. The multibeam-highresolution sonar, acoustic reflectivity, and acoustics for sediments penetration (about $150 \mathrm{~m}$ strata) data illustrate continental deformations related with the $70 \mathrm{~km}$-long active faulting landslide (Megasplay in figure 1) located in the accretionary prism in front of the subduction zone graben (Convemar, 2010). Hazards of submarine mega-landslides have been delineated from bathymetric data, allowing to reconstruct their sedimentary paleo-environment. This reconstruction has been performed assuming that these processes have been potentially active in past glacial periods when the sea level stood 120 meters below the current sea level (Bintanja et al., 2005; Rohling et al., 2009;

${ }^{2}$ CEPE (Corporación Estatal Petrolera Ecuatoriana). 1986. El Estudio de la Cuenca del Golfo de Guayaquil. Informe integrado para la Corporación Estatal Petrolera Ecuatoriana. Reporte técnico: 129 p. 
Elderfield et al., 2012; Chunga and Quiñónez, 2013). Near the graben areas, continental slopes are highly unstable and able to produce submarine landslides, causing re-deposition into depressed areas (Fig. 2). In the intermediate slopes are well-structured and noticeable submarine canyons (e.g., Santa Elena Canyon), where high erosion rates demonstrate the geometry of structures with strong incisions in the seafloor. The Guayaquil canyon, located southward, also indicates considerable circular submarine landslides scarps (Fig. 2). The identification of a thrust fault with a length of approximately $150 \mathrm{~km}$ has also been documented in the accretionary prism of the Gulf of Guayaquil (Convemar, 2010; Table 2).

\section{Capable faults and shallow earthquakes}

Strong-to-moderate crustal earthquakes in the southern coast of Ecuador have been poorly documented. The historical accounts obtained from the Cuenca and Quito Culture House archives (MHQ, 1879), evidence of the earthquake that hit the city of Guayaquil on June $11^{\text {th }}, 1787$. This earthquake has been associated with a seismic source in the Carrizal faults (F-18) or Estero Salado fault (F-17) located 35 and 16 kilometers, respectively, far from the urban area (Table 2). The macroseismic intensity estimated for this earthquake is between VIII to IX degrees of the ESI-07 scale, while the calculated magnitude

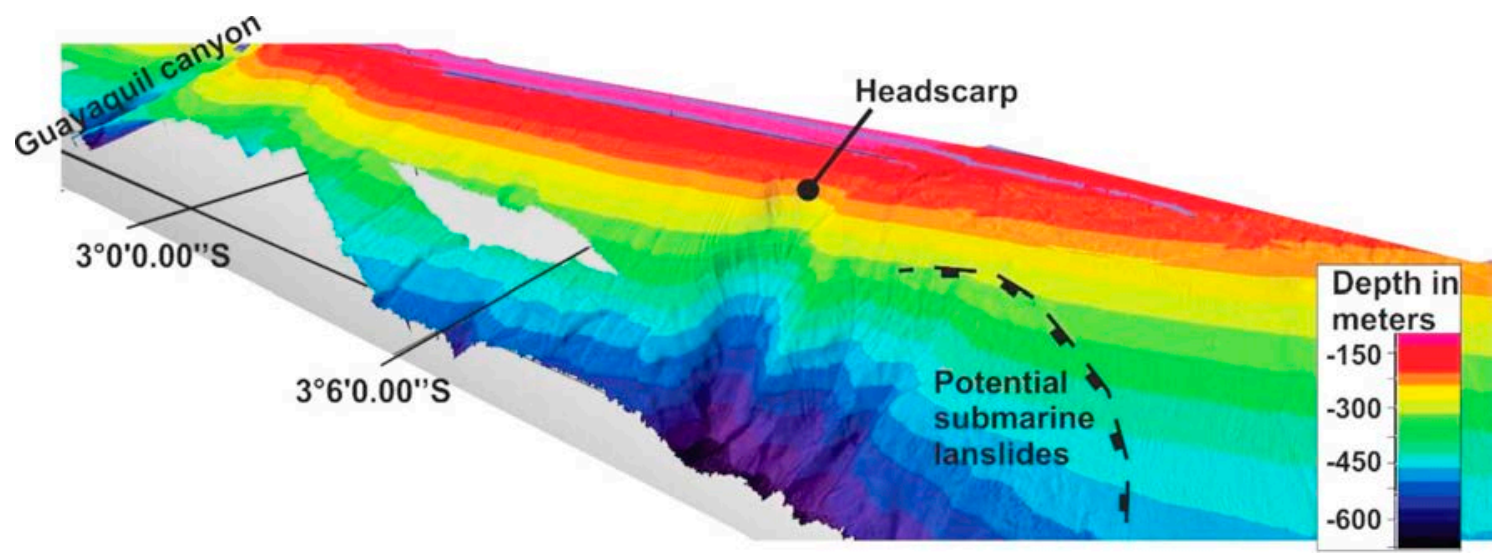

FIG. 2. Submarine landslides have the potential to generate devastating tsunamis next to the Guayaquil canyon, within the Guayaquil Gulf.

TABLE 2. CHARACTERIZATION OF SEISMIC SOURCE FOR THE GUAYAQUIL EARTHQUAKE OF 11.06.1787 AND ITS POSSIBLE TECTONIC ASSOCIATION WITH THE ESTERO SALADO FAULT (F17) AND/OR THE CARRIZAL FAULT (F18).

\begin{tabular}{cccccc}
\hline $\begin{array}{c}\text { Seismogenic } \\
\text { structure }\end{array}$ & Fault type & $\begin{array}{c}\text { Estimated } \\
\text { Fault length } \\
(\mathbf{k m})\end{array}$ & $\begin{array}{c}\text { Distance of } \\
\text { seismic source } \\
\mathbf{( k m )}\end{array}$ & $\begin{array}{c}\text { Fault direction } \\
\text { (azimuth) }\end{array}$ & $\begin{array}{c}\text { Estimated } \\
\text { dip of fault }\end{array}$ \\
\hline $\begin{array}{c}\text { F. Estero Salado } \\
\text { (F17) }\end{array}$ & Normal & 57 & 25 & 40 & 45 al SE \\
F. Carrizal (F18) & Normal & 36 & 20 & 105 & 45 al SW \\
\hline $\begin{array}{c}\text { Calculated } \\
\text { Magnitude }\end{array}$ & $\begin{array}{c}\text { Estimated } \\
\text { Magnitude }\end{array}$ & $\begin{array}{c}\text { Reliability } \\
\text { levels for faults }\end{array}$ & $\begin{array}{c}\text { Historical } \\
\text { earthquake }\end{array}$ & $\begin{array}{c}\text { Environment } \\
\text { Seismic Intensity }\end{array}$ & $\begin{array}{c}\text { Proposed } \\
\text { Epicenter }\end{array}$ \\
\hline 7.1 & $\geq 6$ & True (I) & Lat. -2.379 \\
6.9 & $\geq 6$ & Deductible (II) & 11.06 .1787 & VIII & Long. - 80.111 \\
\hline
\end{tabular}

Calculated magnitude based on Well and Coppermisth (1994); Estimated Magnitude from morpho-structural Zonation based on Chunga (2010); Fault length estimated from morphological analysis; Reliability levels for faults are from seismological and morphological analyzes. 
ranges between Mw 6 to Mw 6.5 (Chunga, 2010; Chunga et al., 2013). Another Mw 6.2 earthquake, (i.e., Ruffilli, 19483) occurred in 1943, in the Guayaquil area. Historical records suggest that this earthquake was accompanied by a strong underground noise related to a massive landslide in a nearby quarry.

The coseismic effects on the ground allowed to assume that the earthquake epicenter was located quite close to the urban area. The subjective perception of the Guayaquil inhabitants is that this earthquake was more violent and shorter than the one occurred on May 13, 1942. The earthquake of August 18, 1980, of magnitude $\mathrm{Mw}$ 6.1, had its epicenter located 28 kilometers northwest of the city of Guayaquil (Fig. 3). The macroseismic intensity values varied from VII to VIII degrees on the Mercalli scale (Egred, 1975; Mera, 1999; Chunga et al., 2005a). Multiple houses collapses, as well as telephone and electrical services, were interrupted. The earthquake was felt strongly in the southern, western, and central area of the city. Argudo et al. (1993) described the damages of old buildings where 29 walls of houses collapsed with the partial or destruction of seven of them (Fig. 4). Further evaluations determined that 49 houses needed later demolition. In the historical accounts, the housing damages and the levels of human perception of quakes were described. However, these seismic events certainly generated earthquake environmental effects on the ground that probably were not described. The homes grounded in soft clayey soils in the southwest part of the city may have suffered accelerations of the natural subsidence rate, sinkholes, and soil liquefactions processes. Guayaquil also has hills with unstable slopes where rock falls or landslides may have occurred but remained undocumented.

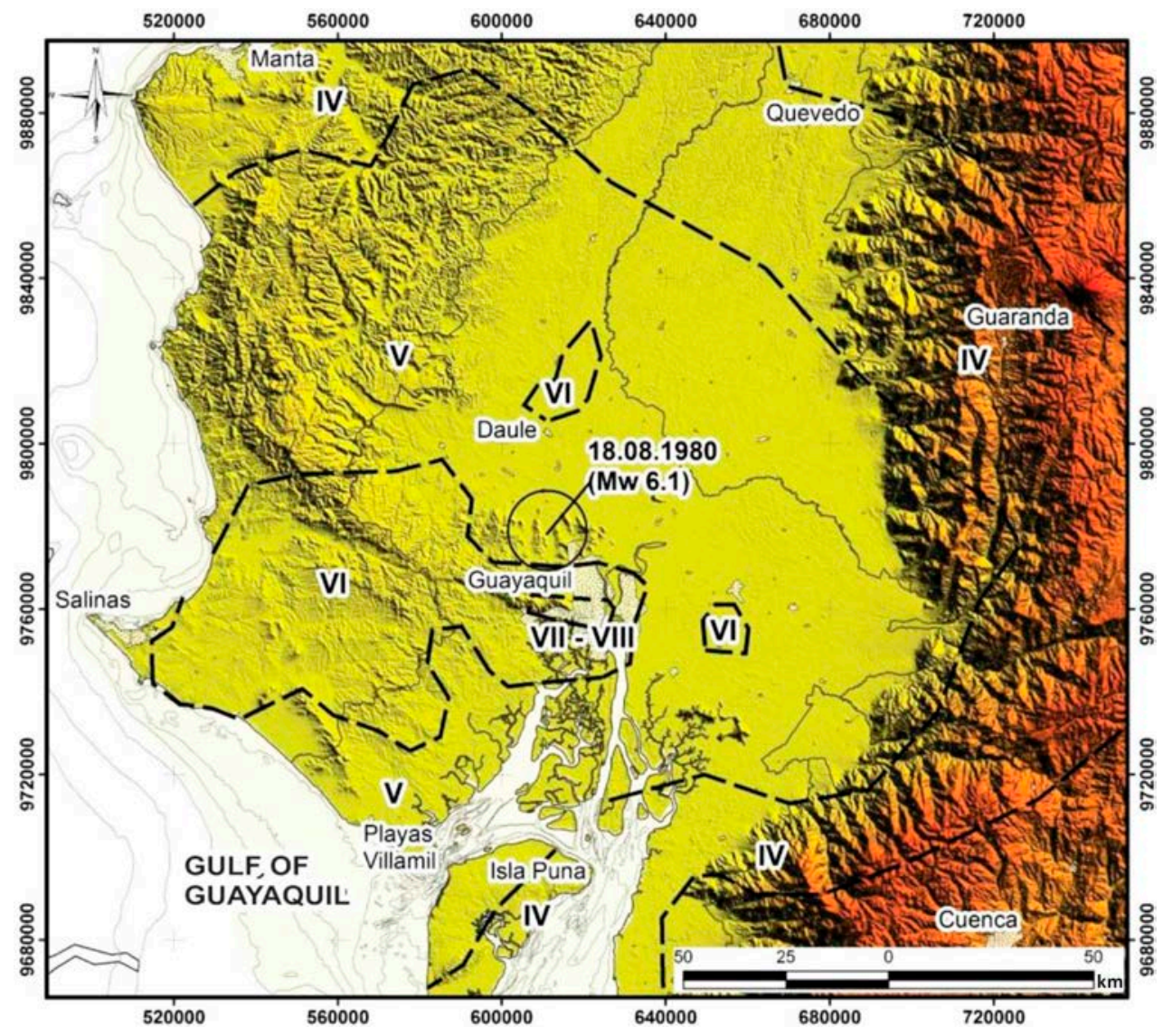

FIG. 3. Map of macroseismic intensities (IMM, Mercalli scale). proposed by Egred (1975) for the earthquake of August 18, 1980 (Mw 6.1).

${ }^{3}$ Ruffilli, A. 1948. Lecciones de Estructuras. Universidad de Guayaquil (Inédito): 422 p. 

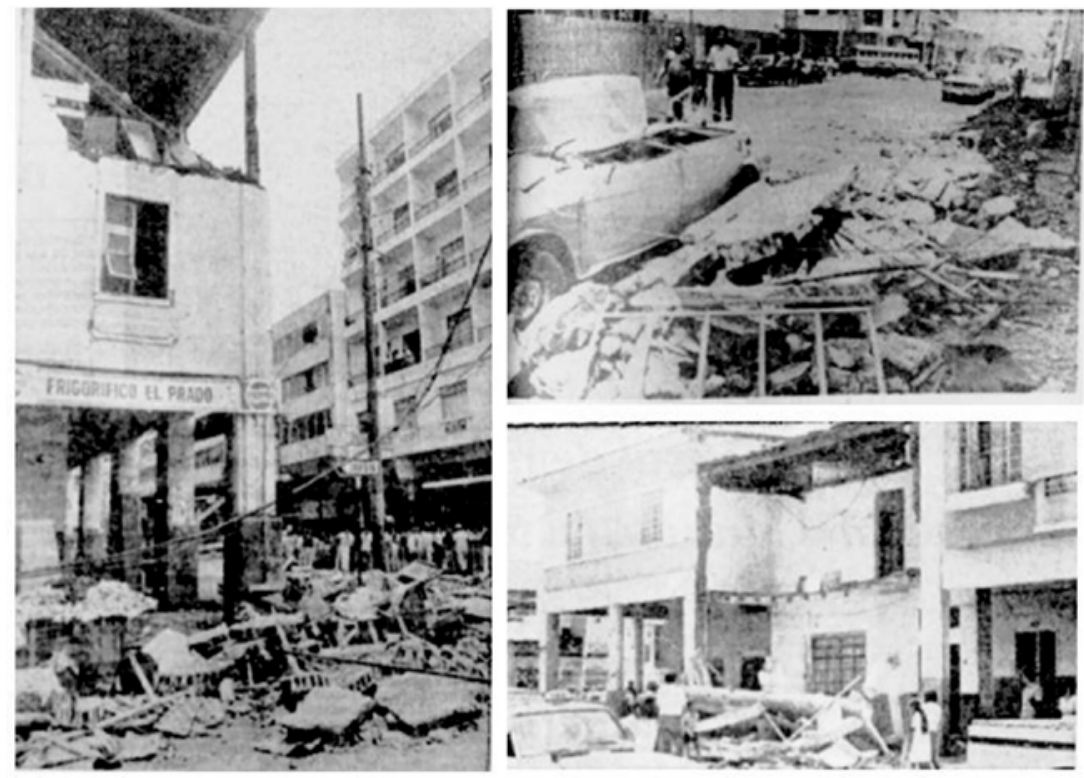

FIG. 4. Building damages during the earthquake of August 18, 1980. Photos taken by the local daily newspaper "El Universo" (Argudo et al., 1993).

\section{Estimation of the maximum magnitude and PGA}

Instrumental data of earthquakes with magnitudes higher than Mw 6 and their association with crustal capable faults are poorly documented in the Gulf of Guayaquil. In this context, it is defined as a "capable fault" the type of fault that may be a potential source of future earthquakes. It presents evidence of dislocations or surface displacements occurred in the last 30,000 years, and if the historical seismicity can be linked with a precise fault (IAEA, 2002; Chunga, 2010). Moreover, a fault is considered "potentially active," as a potential source for future earthquakes, if the surface dislocations occurred at least in the last 50,000 years (IAEA, 2002; Robert and Michetti, 2004; Michetti et al., 2007).

To estimate the seismicity associated with a crustal fault in the southern coast of Ecuador, a catalog with 40 faults capable of deforming the ground surface and to generate modest-to-strong earthquakes $(6.2<\mathrm{Mw}$ $<7.2)$ was compiled. The database includes faults recognized at the seafloor and on the continental area of the Santa Elena, El Oro, and The Guayas provinces (Table 3). Relevant information about the geometry and kinematics movements of each fault, as well as evidence of vertical displacement from late Pleistocene to the Holocene has been provided by numerous studies (CEPE, 1986; Eguez et al., 2003;
Dumont et al., 2005; Witt et al., 2006; Calahorrano et al., 2008; Witt and Bourgois, 2010; Cobos and Montenegro, 2010). Seismic profiles available from EP-Petroecuador were interpreted by CEPE (1986), and they documented that many of the faults do not reach the ground surface because they are covered by late Pleistocene to Holocene sediments. In this study, this kind of faults was classified as "active" and unable. Knowing the fault features allows evaluating possible earthquakes and their features as magnitude, macroseismic intensity, and PGA.

The geometric parameters considered for each selected fault includes: 1) the fault spatial projection on the surface, 2) the fault geometry and kinematics, 3) the structural dip and fault displacement angle estimated (rake), and 4) seismogenic structure width. Based on the described parameters, the faults have been modeled with several short segments instead of long segments (Fig. 5; Chunga, 2010). The historical seismicity of the Guayaquil gulf show seism with $\mathrm{Mw}$ comprise between 6 and 7.1 and a recurrence time lower than 15 years. These data can be justified only with fault with longitude lower than 70 kilometers. For this reason, the maximum estimated magnitude will be lower, and the fault slip rate requires of many smaller earthquakes to accommodate a cumulative seismic moment (Well and Coppersmith, 1994). 


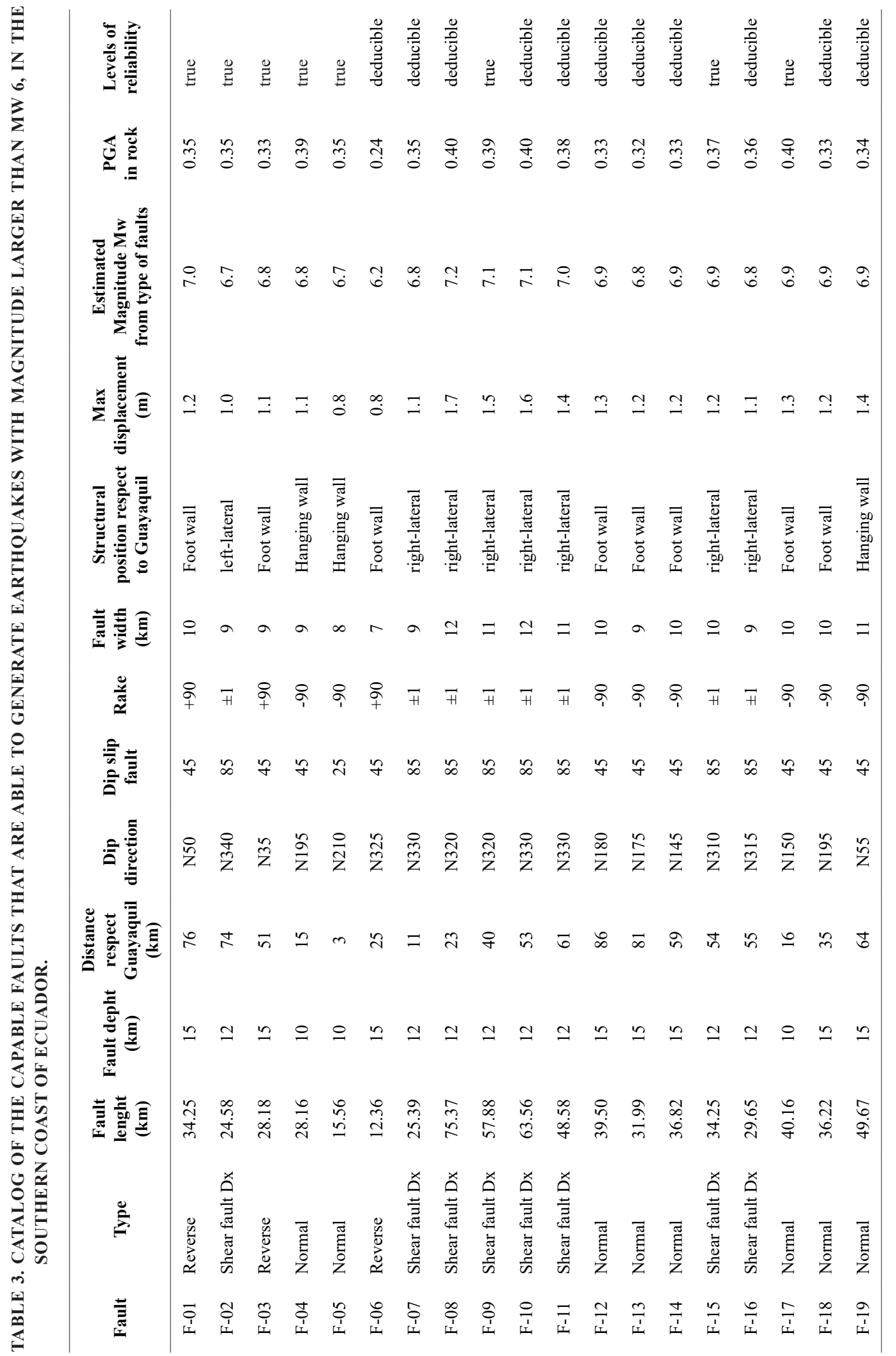




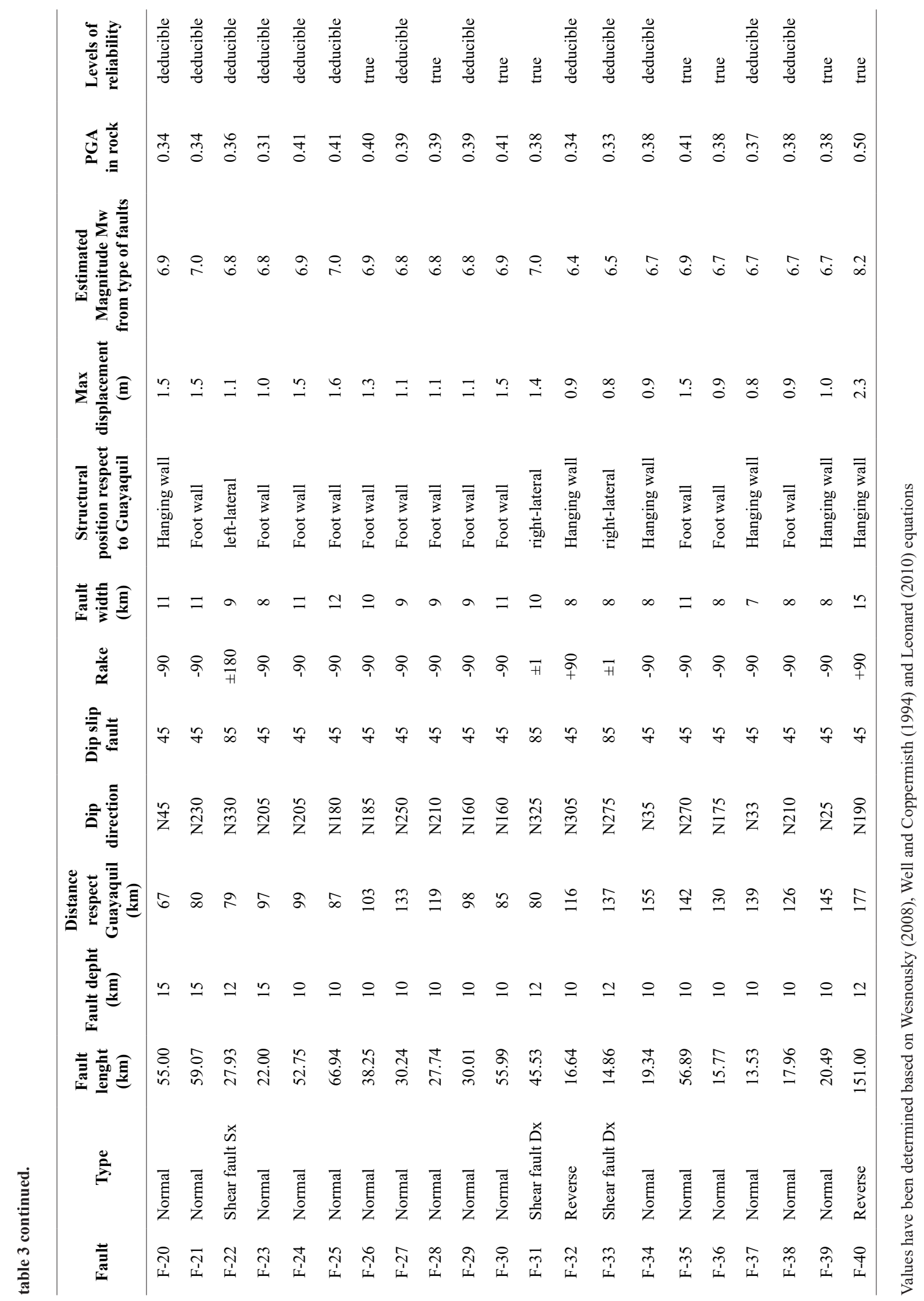



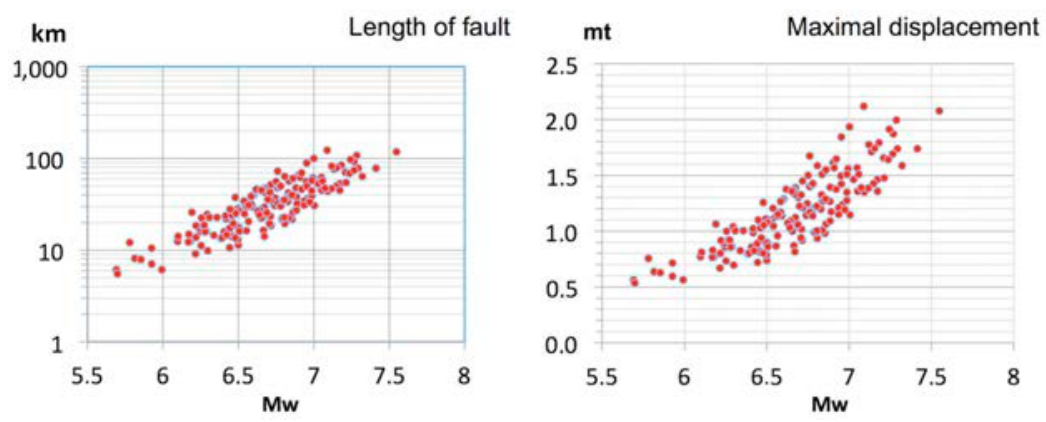

FIG. 5. Maximum Credible Earthquakes (MCEs) generated by fault segments capable in Ecuador (Chunga, 2010), confirms the relationship between length and vertical displacement of crustal faults in the Gulf of Guayaquil.

The most appropriate approach to estimate the maximum magnitude of an earthquake is a relationship with the fault rupture length. The maximum magnitudes for each of the crustal faults identified, and the maximum vertical displacement, are estimated with the empirical regression relationships (magnitude earthquake/displacement of geological fault) given by Well and Coppersmith (1994).

Magnitude estimate $(\mathrm{Mw})=5.08+1.16 * \log _{10}\left(\mathrm{~L}_{\mathrm{f}}\right)$

Fault displacement $(\mathrm{m})=\exp \left(-1.38+1.02 * \log _{10}\left(\mathrm{~L}_{\mathrm{f}}\right)(2)\right.$

In equations 1 and $2, \mathrm{~L}_{\mathrm{f}}$ is the capable fault length.

Leonard (2010) proposed changes and corrections on the relation used to estimate the maximum magnitudes, providing the equations,

$\mathrm{Mw}=\mathrm{a} * \log \left(\mathrm{L}_{\mathrm{f}}\right)+\mathrm{b}$

In equation $3, a=1.52$ and $b=4.33$. The estimated magnitude is given by the equation 4 :

$\left(\mathrm{M}_{\mathrm{e}}\right)=1,52 * \log _{10}\left(\mathrm{~L}_{\mathrm{f}}\right)+4,33$

Similarly, Wesnousky (2008), proposed other relations for each type of capable faults:

Shear faults: $\mathrm{Mw}=5.56+0.87 * \log \left(\mathrm{L}_{\mathrm{f}}\right)$

Normal faults: $\mathrm{Mw}=6.12+0.47 * \log \left(\mathrm{L}_{\mathrm{f}}\right)$

Reverse faults: $\mathrm{Mw}=4.11+1.88 * \log \left(\mathrm{L}_{\mathrm{f}}\right)$
These regression equations show that different kind of faults, with the same dimension, may generate earthquakes with different magnitudes (Wesnousky, 2008; Stirling et al., 2013). This information was applied on the capable faults outlined in the Gulf of Guayaquil (Fig. 6). The reverse faults are considered capable of generating earthquakes higher than those of equal length but related with shears and normal faults. Another value that we have estimated is the Peak Ground Acceleration (PGA) and used the equation proposed by Fukushima and Tanaka (1990).

$\mathrm{PGA}_{\text {estimated }}=\left(10^{\wedge}\left(0,41 * \mathrm{M}_{\mathrm{e}}-\log _{10}\left(\mathrm{H}_{\mathrm{f}}+0,032 * 10^{\wedge}\right.\right.\right.$ $\left.\left.\left.\left(0,41 * \mathrm{M}_{\mathrm{e}}\right)\right)-0,0034 * \mathrm{H}_{\mathrm{f}}+1,3\right)\right) / 980$

In equation $8, \mathrm{H}_{\mathrm{f}}$ is the depth of fault and $\mathrm{M}_{\mathrm{e}}$ the estimated magnitude.

The PGA estimated in the analysis ranges from $0.24 \mathrm{~g}$ to $0.41 \mathrm{~g}$ (Table 3 ). These PGA values may be compared with the seismic zonation map of Ecuador (NEC, 2011; Fig.7). The reliability levels for each of the capable fault have been implemented from seismological (instrumental earthquake records outlined along the structure) and morphological (fault scarps or delineation of reliefs associated with lifting or tectonic subsidence) analysis. Three main categories of capable faults are recognized, being true "I," deductible "II," and uncertain or hypothetical "III" (Table 3). For a reliability level of being "true," it has been required that the geological faults present evidence of dislocation on the ground, seismicity, and lateral displacement during the Quaternary. For a "deduced" level the fault must present displacement

\footnotetext{
${ }^{4}$ NEC (Norma Ecuatoriana de la Construcción). 2011. Cargas Sísmicas, Diseño Sismo Resistente. Capítulo 2: Peligrosidad Sísmica. Cámara de la Construcción de Pichincha: 139 p.
} 


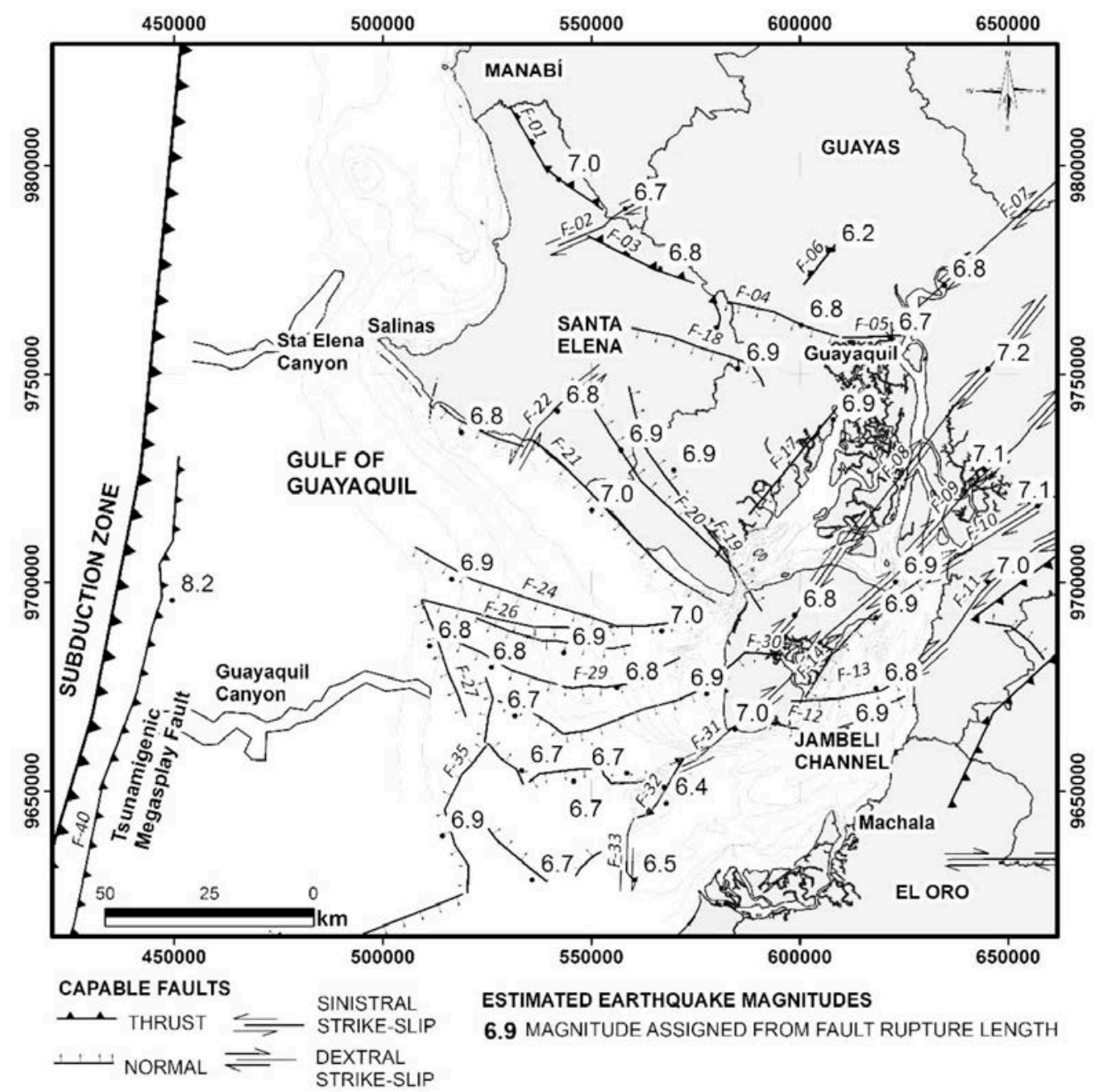

FIG. 6. Estimation of the maximum probable magnitudes obtained from the analysis of capable fault using the equations proposed by Wesnousky (2008). F-01 to F-40 indicate the geological faults outlined in the southern coast of Ecuador. Crustal faults have been delineated from Chunga (2010), Chunga and Quiñónez (2013), Cobos and Montenegro (2010), Eguez et al. (2003), Witt et al. (2006), Witt and Bourgois (2010).

or dislocation evidence that may be distinguished on the morphometry relief. Finally, the hypothetical level corresponds when the structural guidelines may be associated with an active fault, but the displacement cannot be recognized, or where the epicenter of the earthquakes are aligned, with the hypocenter being less than $20 \mathrm{~km}$ in depth.

\section{Discussion and conclusions}

Forty crustal faults capable of generating earthquakes in the Gulf of Guayaquil have been identified. The relation proposed by Wesnousky (2008) allowed to estimate the associated maximum magnitudes and PGA values in the Gulf of Guayaquil and the coastal segment of the southern part of continental Ecuador.

These faults may generate earthquakes with magnitudes ranging from $\mathrm{Mw} 6.2$ to $\mathrm{Mw}$ 7.2. The F-40 reverse fault, located $177 \mathrm{SW} \mathrm{km}$ west of the city of Guayaquil, on the accretionary prism area (opposite respect to the subduction zone), has a length of approximately $150 \mathrm{~km}$ and can generate a potential earthquake of magnitude $\mathrm{Mw} 8.2$, and a PGA of $0.50 \mathrm{~g}$. 


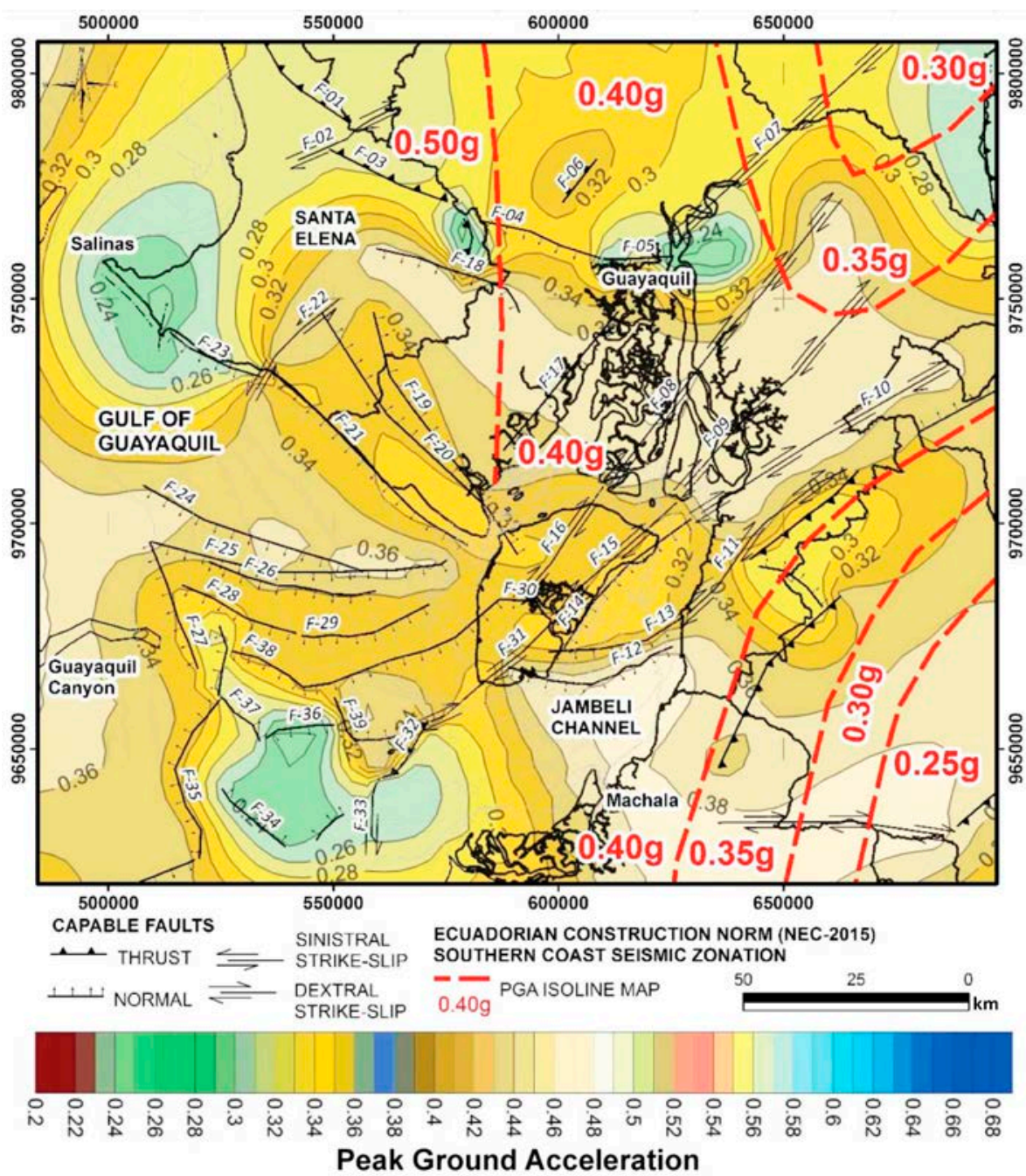

FIG. 7. Estimation of maximum PGA (Peak Ground Acceleration) obtained from the analysis of capable faults using the method proposed by Fukushima and Tanaka (1990). F-01 to F-40 indicate the geological faults outlined in the southern coast of Ecuador. The graphical representation of the analytically determined values were plotted using the Arcgis and Surfer software, by using the interpolation by "gridding" creating an iso-values map.

The southern coastal area of Ecuador, including Guayaquil, is a densely-populated area with an important strategic industrial sector as well as a petroleum refinery. In this area, earthquakes with a magnitude between $\mathrm{Mw} 7$ and $\mathrm{Mw}$ 7.2, and PGA values from $0.34 \mathrm{~g}$ to $0.41 \mathrm{~g}$ may be generated in a range of 23 and $80 \mathrm{~km}$ with respect to the city of Guayaquil. The crustal faults delineated and analyzed, which could generate these strong earthquakes are: F-01, F-08, F-09, F-10, F-11, F-21, F-25, and F-31. They are dextral shear faults, located to the north of the Island of Puná (Fig. 6).
The normal fault F-05 (Fig. 8), located $3 \mathrm{~km}$ east of Guayaquil, has a fault striking $\mathrm{N} 300^{\circ}$ and dipping $\mathrm{N} 25^{\circ} \mathrm{S}-\mathrm{SW}$. Based on analysis of morphotectonic features, an earthquake of magnitude Mw 6.7 and a PGA value of $0.35 \mathrm{~g}$ is estimated. This fault is evident in a quarry having a parallel trend with the strata direction $(210 / 25)$ of limestones and shales of the San Eduardo and Guayaquil formations (Fig. 8). The Carrizal fault (F-18) or the Estero Salado fault (F-17) has been the responsible of the seismic event passed on June $11^{\text {th }}, 1787$ (macroseismic intensity VIII; Chunga, 2010). Both structures have well-defined 


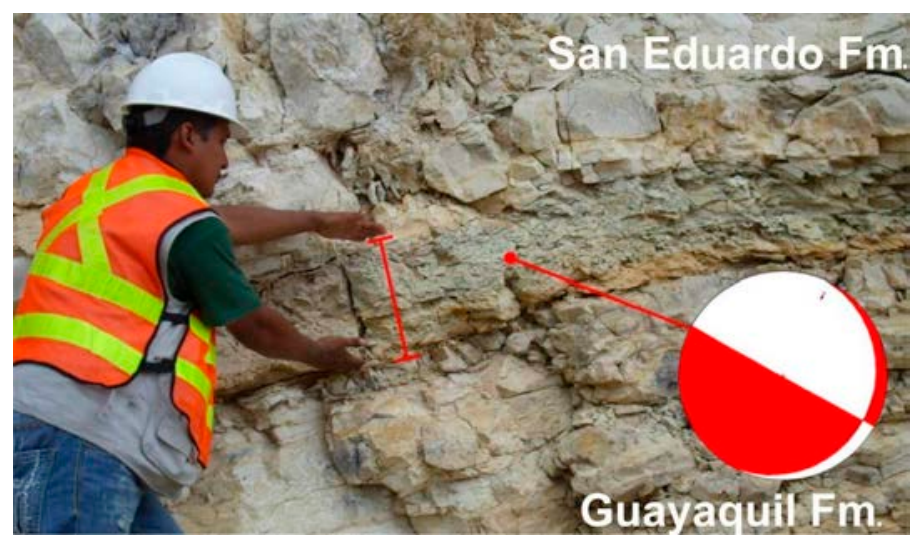

FIG. 8. F-05 Fault with parallel trend respect to the contact between the rocks of the Guayaquil and San Eduardo formations, Holcim quarry, Guayaquil city.

morphological and seismological features and an "educated guess" of the PGA of $0.33 \mathrm{~g}$. This value has been estimated from the hypocentral distance of the faults being located between 10 and $16 \mathrm{~km}$ depth, and the maximum magnitudes have been estimated to be Mw 6.7, approximately.

For the sub-basin of Esperanza, located in the seafloor of the Gulf of Guayaquil, faults F-24 to F38 (Table 2) are identified as capable faults with estimated PGA values on the rock between $0.33 \mathrm{~g}$ and $0.41 \mathrm{~g}$. In this segment of the continental shelf, the maximum estimated magnitudes have values between Mw 6.4 and $\mathrm{Mw}$ 7.0. The maximum vertical displacements have been estimated between 0.8 to $1.6 \mathrm{~m}$.

The historical records illustrate that Guayaquil, the most populated city in Ecuador, may be prone to strong earthquake-induced damage, with coseismic effects on the surface, by moderate local earthquakes and very strong of, even, distant earthquakes of magnitude higher than $\mathrm{Mw}$ 7.8.

\section{Acknowledgements}

This work was supported by the Centro de Investigaciones de Geociencias de la Universidad Estatal Península de Santa Elena (CIGEO-UPSE). The authors are also grateful to the anonymous reviewers for the constructive comments that helped in improving this paper.

\section{References}

Abe, K. 1979. Size of great earthquakes of 1837-1974 inferred from tsunami data. Journal of Geophysical Research, Solid Earth 84 (B4): 1561-1568.
Aguiar, R.; Quizanga, D.; López-Moreno E. 2016. V/H spectral ratios associated with reverse faults of Quito city. Boletín de Ciencias de la Tierra 42: 1-11.

Argudo, J.; Bravo, F.; Yela, R. 1993. Metodología para la reducción de la vulnerabilidad sísmica de escuelas y bibliotecas en Guayaquil. La Educación 115: II.

Arreaga, P.; Ortiz, M. 2002. Análisis de riesgo por tsunamis en el Golfo de Guayaquil. Acta Oceanográfica del Pacífico 11 (1): 23-29.

Barazangi, M.; Isacks, B.L. 1976. Spatial distribution of earthquakes and subduction of the Nazca plate beneath South America. Geology 4: 686-692.

Bintanja, R.; Van de Wal, R.S.W.; Oerlemans, J. 2005. Modelled atmospheric temperatures and global sea level over the past million years. Nature 437: 125-128.

Calahorrano, A.; Sallares, V.; Collot, J.-Y.; Sage, F.; Ranero, C.R. 2008. Nonlinear variations of the physical properties along the southern Ecuador subduction channel: Results from depth-migrated seismic data. Earth and Planetary Science Letters 267 (3-4): 453-467.

Chunga, K. 2010. Shallow crustal earthquakes and seismic zonation for Ecuador through the integration of geological, seismological and morphostructural data. Ph.D. Thesis (Unpublished), University of Insubria: $165 \mathrm{p}$.

Chunga, K.; Quiñónez, M. 2013. Evidencia de un depósito sedimentario de tsunamis en la planicie aluvial de Villamil Playas, Golfo de Guayaquil. Revista Acta Oceanográfica del Pacífico 18 (1): 163-180.

Chunga, K.; León, C.; Quiñónez, M.F.; Benítez, S.; Montenegro, G. 2005a. Seismic Hazard Assessment for 
Guayaquil City (Ecuador): Insights from Quaternary Geological Data. In Abstract Final Meeting, Dark Nature, Rapid natural Change and Human Responses 55-56. Como, Italy. http://at.yorku.ca/c/a/q/y/47.htm (last visit 09/11/2018).

Chunga, K.; Zamudio, Y.; Egred, J.; Marín, G.; Quiñónez, M.; Iturralde, D. 2005b. The 12 Dic, 1953, Earthquake, Ms 7.3, Ecuador-Peru Border Region: A case study for applying the New INQUA Intensity Scale. In Abstract Final Meeting, Dark Nature, Rapid natural Change and Human Responses: 57-58. Como. http://at.yorku. $\mathrm{ca} / \mathrm{c} / \mathrm{a} / \mathrm{q} / \mathrm{y} / 56 . \mathrm{htm}$ (last visit 09/11/2018).

Chunga, K.; Martillo, C.; Pazmiño, N.; Quiñónez, M.F.; Huaman, F. 2013. Estimaciones de máximos niveles de sismicidad para el Litoral Ecuatoriano a través de la integración de datos geológicos y sismotectónicos. Revista Científica y Tecnológica UPSE: 73-86.

Cobos, L.; Montenegro, G. 2010. Estudio integrado del Golfo de Guayaquil del Mioceno al reciente. Revista CICYT-ESPOL: 1-8.

Contreras, M. 2013. Cronología de Tsunamis en Ecuador desde 1586 a 2012. Revista La Técnica 11: 50-59.

Convemar, 2010. Reporte científico a bordo del B.I.91 "ORION" para el estudio geológico del margen de plataforma continental del Golfo de Guayaquil (GEMAC). CNDM (Convención Nacional de Derecho del Mar) del INOCAR, Reporte Técnico: 66 p.

Costa, C.H.; Audermard, M.F.A.; Bezerra, F.H.R.; Lavenu, A.; Machette M.N.; Paris, G. 2006. An Overview of the Main Quaternary Deformation of South America. Asociación Geológica Argentina 61 (4): 461-479. Buenos Aires.

De Mets, C.; Gordon, R.G.; Argus, D.F.; Stein, S. 1990. Current plate motions. Geophysical Journal International 101: 425-478.

Dumont, J.F.; Santana, E.; Vilema, W. 2005. Morphologic evidence of active motion of the Zambapala Fault, Gulf of Guayaquil (Ecuador). Geomorphology 65 (3): 223-239.

Dumont, J.F.; Santana, E.; Bonnardot, M.A.; Pazmiño, N.; Pedoja, K.; Scalabrino, B. 2014. Geometry of the coastline and morphology of the convergent continental margin of Ecuador. Geological Society, Memoirs 41 (1): 327-338. London.

Egred, J. 1975. Breve historia de los principales terremotos ecuatorianos. Revista Geofísica 3: 21-36. México, D.F.

Eguez, A.; Alvarado, A.; Yepes, H.; Machette, M.N.; Costa, C.H.; Dart, R.L.; Bradley, L.-A. 2003. Database and map of Quaternary faults and folds of Ecuador and its offshore regions. U.S. Geological Survey OpenFile Report: 03-289.

Elderfield, H.; Ferretti, P.; Greaves, M.; Crowhurst, S.; McCave, I.N.; Hodell, D.; Piotrowski, A.M. 2012. Evolution of ocean temperature and ice volume through the mid-Pleistocene climate transition. Science 337: 704-709.

Espinoza, J. 1992. Terremotos Tsunamigénicos en el Ecuador. Acta Oceanográfica del Pacífico 7 (1): 21-28.

Freymuller, J.T.; Kellogg, J.N.; Vega, V. 1993: Plate motions in the north Andean region. Journal of Geophysical Research 98: 21853-21863.

Fukushima, Y.; Tanaka, T. 1990. A New Attenuation Relation for Peak Horizontal Acceleration of Strong Earthquake Ground Motion in Japan. Bulletin of the Seismological Society of America 80 (4): 757-783.

Gutscher, M.A.; Malavieille, J.; Lallemand, S.E.; Collot, J.Y. 1999. Tectonic segmentation of the North Andean margin: Impact of the Carnegie Ridge collision. Earth and Planetary Science Letters 168: 255-270.

Hughes, R.A.; Pilatasig, L.F. 2002. Cretaceous and Tertiary terrane accretion in the Cordillera Occidental of the Andes of Ecuador. Tectonophysics 345: 29-48.

IAEA Safety Standards Series 2002. Evaluation of Seismic Hazards for Nuclear Power Plants. Safety Guide NSG-3.3. International Atomic Energy Agency: 31 p.

Ioualalen, M.; Monfret, T.; Bétoux, N.; Chlieh, M.; PonceAdams, G.; Collot, J-Y.; Martillo, C.; Chunga, K.; Navarrete, E.; Montenegro, G.; Solis-Gordillo, G. 2014. Tsunami mapping in the Gulf of Guayaquil, Ecuador, due to local seismicity. Marine Geophysical Research Journal 35 (4): 361-378. doi: 10.1007/ s11001-014-9225-9.

Jaillard, E.; Ordóñez, M.; Benitz, S.; Jimenez, G.; Montengro, N.; Zambrano, G. 1995. Basin development in an accretionary, oceanic-floored fore-arc setting: southern coastal Ecuador during Late Cretaceous-Late Eocene times. In Petroleum Basins of South America. American Association of Petroleum Geologists (Welsink, H.J.; Suárez, S.R.a.; Tankard, A.J.; editors) Memoir 62: 615-631.

Kanamori, H. 1977. The energy release in great earthquakes. Journal of Geophysical Research 82 (20): 2981-2987.

Kellogg, J.N.; Vega, V. 1995. Tectonic development of Panama, Costa Rica and the Colombian Andes: Constraints from Global Positioning System geodetic studies and gravity. Geological Society of America, Special Paper 295: 75-90. 
Leonard, M. 2010. Earthquake fault scaling: Self consistent relating of rupture length width, average displacement, and moment release. Bulletin of the Seismological Society of America 100 (5A): 1971-1988.

Lonsdale, P. 1978. Ecuadorian Subduction System. The American Association of Petroleum Geologists Bulletin 62 (12): 2454-2477.

Marín, J.P.; Salcedo, E.; Castillo, H. 2008. Relaciones empíricas entre parámetros instrumentales y macrosísmicos de algunos terremotos fuertes de Colombia. Boletín de Geología 30 (1): 99-111.

Mendoza, C.; Dewey, J.W. 1984. Seismicity associated with the great Colombia-Ecuador earthquakes of 1942, 1958, and 1979: Implications for barrier models of earthquake rupture. Bulletin of the Seismological Society of America 74 (2): 577-593.

Mera, W. 1999. Seismic hazard and countermeasures in Guayaquil. Bulletin of the International Institute of Seismology and Earthquake Engineering 33: 163-178.

MHQ, 1879. Relación del terremoto que asoló a Guayaquil el 11 de junio de 1787. Museo Histórico, Órgano del Museo de Historia de las ciudades de Cuenca y Quito: 41-42. Ecuador.

Michetti, A.M.; Esposito, E.; Guerrieri, L.; Pórfido, S.; Serva, L.; Tatevossian, R.; Vittori, E.; Audemard, F.; Azuma, T.; Clague, J.; Comerci, V.; Gürpinar, A.; McCalpin, J.; Mohammadioun, B.; Mörner, N.A.; Ota, Y.; Rogozhin, E. 2007. Intensity Scale ESI 2007, La Scala di Intensità ESI 2007 (Guerrieri, L.; Vittori, E.; editors). Servizio Geologico d'Italia, Dipartimento Difesa del Suolo, APAT (Agenzia per la protezionedell'ambiente e per i servizi tecnici). Carta Geologica D'Italia 74: 41 p. Roma. http:// www.apat.gov.it/site/it-IT/Progetti/-INQUA_Scale/ (last visit 11/07/2018).

NEIC (National Earthquake Information Center). 2017. http://neic.usgs.gov/ (last visit 15/03/2016).

Robert, G.P.; Michetti, A.M. 2004. Spatial and temporal variations in growth rates along active normal fault systems: an example from The Lazio-Abruzzo Apennines, central Italy. Journal of Structural Geology 26: 339-376.

Rohling, E.J.; Grant, K.; Bolshaw, M.; Roberts, A.P.; Siddall, M.; Hemleben, C.; Kucera, M. 2009. Antarctic temperature and global sea level closely coupled over the past five glacial cycles. Nature Geoscience 2: 500-504.
Shumway, G. 1954. Carnegie ridge and cocos ridge in the East Equatorial Pacific. The Journal of Geology 62 (6): 573-586.

Silgado, F.E. 1957. El movimiento sísmico del 12 de diciembre de 1953. Boletín de la Sociedad Geológica del Perú 32 (2): 225-238.

Stirling, M.; Goded, T.; Berryman, K.; Litchfield, N. 2013. Selection of earthquake scaling relationships for seismic-hazard analysis. Bulletin of the Seismological Society of America 103 (6): 2993-3011. doi: 10.1785/0120130052.

Toulkeridis, T. 2011. Volcanic Galápagos Volcánico. Ediecuatorial: 364 p. Quito.

Trenkamp, R.; Kellogg, J.N.; Freymueller, J.T.; Mora, H.P. 2002. Wide plate margin deformation, southern Central America and northwestern South America, CASA GPS observations. Journal of South American Earth Sciences 15: 157-171.

Veloza, G.; Styron, R.; Taylor, M.; Mora, A. 2012. Opensource archive of active faults for northwest South America. GSA Today 22 (10): 4-10.

Wells, D.L.; Coppersmith, K.J. 1994. New empirical relationships among magnitude, rupture length, rupture width, rupture area, and surface displacement. Bulletin of the Seismological Society of America 84: 974-1002.

Wesnousky, 2008. Displacement and geometrical characteristics of earthquake surface ruptures: issues and implications for seismic-hazard analysis and the process of earthquake rupture. Bulletin of the Seismological Society of America 98 (4): 1609-1632. doi: 10.1785/0120070111.

White, S.M.; Trenkamp, R.; Kellogg, J.N. 2003. Recent crustal deformation and the earthquake cycle along the Ecuador-Colombia subduction zone. Earth and Planetary Science Letters 216 (3): 231-242.

Witt, C.; Bourgois J. 2010. Forearc basin formation in the tectonic wake of a collision-driven, coastwise migrating crustal block: The example of the North Andean block and the extensional Gulf of GuayaquilTumbes Basin (Ecuador-Peru border area). GSA Bulletin 122 (1-2): 89-108. doi: 10.1130/B26386.1.

Witt, C.; Bourgois, J.; Michaud, F.; Ordónez, M.; Jiménez, N.; Sosson, M. 2006. Development of the Gulf of Guayaquil (Ecuador) during the Quaternary as an effect of the North Andean block tectonic escape. Tectonics 25: TC3017. doi:10.1029/2004TC001723. 